\title{
Visual Field Defect
}

National Cancer Institute

\section{Source}

National Cancer Institute. Visual Field Defect. NCI Thesaurus. Code C118727.

An absolute or relative reduction in the extent of the normal field of vision. 